\title{
Chenopodium ambrosioides L. essential oil and ethanol extract on control of canine Ancylostoma spp.
}

\section{Extrato etanólico e óleo essencial de Chenopodium ambrosioides $\mathbf{L}$. no controle de Ancylostoma spp. de cães}

\author{
Jessica Nascimento Moraes Monteiro ${ }^{1}$; Anderson Barros Archanjo ${ }^{2}$; \\ Gabriela Porfirio Passos 3 ; Adilson Vidal Costa ${ }^{4}$; \\ Lenir Cardoso Porfirio5; Isabella Vilhena Freire Martins ${ }^{5 *}$
}

\begin{abstract}
The use of Chenopodium ambrosioides L. has shown to be promising in the management of gastrointestinal nematodes. The objective of this study was to quantitate the yield and characterize the chemical composition of the essential oil of $C$. ambrosioides, as well as to evaluate the in vitro effect of the ethanolic extract and the essential oil in L3 of Ancylostoma spp. and the in vivo effect(s) of the essential oil in dogs. The effects of the ethanol extract and essential oil on Ancylostoma spp. were evaluated in vitro by exposing larvae to the extract at concentrations ranging from $0.005 \mathrm{~g} \mathrm{~mL}^{-1}$ to $0.2 \mathrm{~g} \mathrm{~mL}^{-1}$ and to essential oil at concentrations of 50,100 , and $150 \mu \mathrm{L} \mathrm{mL}^{-1}$. For the in vivo test, 26 healthy dogs, naturally infected by Ancylostoma spp., were divided into three groups: F1 - cookies were administered without active principle; F2 - herbal cookies containing $37.5 \mu \mathrm{L} \mathrm{g}^{-1}$ essential oil of C. ambrosioides L.; F3 - cookies plus a commercial formulation containing febantel, pyrantel, praziquantel, and ivermectin. Complete blood counts and serum biochemistry for AST, ALT, AF, urea, creatinine, total protein, and albumin were performed. The yield of the essential oil was $0.3 \% \mathrm{~m} \mathrm{v}^{-1}$, and its major components included $\alpha$-terpinene $(1.24 \%)$, p-cymene $(4.83 \%)$, and (Z)-ascaridole $(87 \%)$ and $\mathrm{E}(5.04 \%)$ isomers. The concentrations of $C$. ambrosioides $\mathrm{L}$. ethanol extract used were ineffective against Ancylostoma spp. larvae. The essential oil at a concentration of $150 \mu \mathrm{L} \mathrm{mL}^{-1}$ was effective against L3 larvae. In the in vivo study in dogs, the herbal cookies containing C. ambrosioides L essential oil reduced the number of eggs per gram of feces.
\end{abstract}

Key words: Essential oil. Helminths. Herb of Santa Maria. Medicinal plants.

\section{Resumo}

$\mathrm{O}$ uso de Chenopodium ambrosioides L. tem se mostrado promissor no controle de nematoides gastrintestinais. Objetivou-se verificar o rendimento e a composição química do óleo essencial de $C$. ambrosioides, assim como avaliar o efeito in vitro do extrato etanólico e do óleo essencial em L3 de Ancylostoma spp., e o efeito in vivo do óleo essencial para cães. Para a atividade larvicida as larvas de Ancylostoma spp. foram colocadas na presença do extrato etanólico nas concentrações de $0,005 \mathrm{~g} \mathrm{~mL}^{-1}$, $0,01 \mathrm{~g} \mathrm{~mL}^{-1}, 0,02 \mathrm{~g} \mathrm{~mL}^{-1}, 0,03 \mathrm{~g} \mathrm{~mL}^{-1}, 0,04 \mathrm{~g} \mathrm{~mL}^{-1} ; 0,05 \mathrm{~g} \mathrm{~mL}^{-1}, 0,06 \mathrm{~g} \mathrm{~mL}^{-1}, 0,08 \mathrm{~g} \mathrm{~mL}^{-1}, 0,1 \mathrm{~g} \mathrm{~mL}^{-1}, 0,12$

\footnotetext{
${ }^{1}$ Discente, Programa de Pós-Graduação em Ciências Veterinárias, Universidade Federal do Espírito Santo, UFES, Alegre, ES, Brasil. E-mail: jessicanmm@hotmail.com

2 Discente, Programa de Pós-Graduação em Biotecnologia, UFES, Vitória, ES, Brasil. E-mail: andersonarchanjo@gmail.com

3 Discente, Programa de Pós-Graduação em Ciência Animal nos Trópicos, Universidade Federal da Bahia, UFBA, Salvador, BA, Brasil. E-mail: gporfiriopassos@gmail.com

${ }^{4}$ Prof., Departamento de Química e Física, UFES, Alegre, ES, Brasil. E-mail: avcosta@hotmail.com

${ }^{5}$ Profs., Departamento de Medicina Veterinária, UFES, ES, Brasil. E-mail: lenircp52@gmail.com; ivfmartins@gmail.com

* Author for correspondence
} 
$\mathrm{g} \mathrm{mL}^{-1}$ e $0,2 \mathrm{~g} \mathrm{~mL}^{-1}$, do óleo essencial nas concentrações de $50 \mu \mathrm{L} \mathrm{mL}^{-1}, 100 \mu \mathrm{L} \mathrm{mL}^{-1}$ e $150 \mu \mathrm{L} \mathrm{mL}^{-1}$. Para o teste in vivo utilizaram-se 26 cães, hígidos, infectados naturalmente por Ancylostoma spp., divididos em três grupos: F1 - foram administrados biscoitos sem princípio ativo; F2 - biscoitos fitoterápicos com óleo essencial de C. ambrosioides L na concentração de $37,5 \mu \mathrm{L} \mathrm{g}{ }^{-1} ; \mathrm{F} 3$ biscoitos acrescido de formulação comercial a base de febantel, pirantel, praziquantel e ivermectina. Foi realizado hemograma completo e bioquímica sérica para AST, ALT, FA, ureia, creatinina, proteína total e albumina. Verificouse o rendimento de $0,3 \% \mathrm{~m} \mathrm{v}^{-1}$ do óleo essencial e na sua composição química a presença de $\alpha$-terpineno $(1,24$ \%), o p-cimeno ( 4,83 \%) e ascaridol, nos seus isômeros $Z(87 \%)$ e $E(5,04$ \%), como componente majoritário. $\mathrm{O}$ extrato etanólico de $C$. ambrosioides L., nas concentrações utilizadas, apresentou insuficiente atividade para o efeito larvicida. O óleo essencial na concentração de $150 \mu \mathrm{L} \mathrm{mL}^{-1}$ foi eficaz contra $\mathrm{L}_{3}$. A formulação de biscoito fitoterápico com óleo essencial C. ambrosioides $\mathrm{L}$ reduziu o número de ovos por grama de fezes dos cães.

Palavras-chave: Erva-de-santa-maria. Helmintos. Óleo essencial. Planta medicinal.

\section{Introduction}

Chenopodium ambrosioides L., popularly known as Santa Maria herb and Paico, is a medicinal plant of South America, which, for centuries, has been popularly used for its medicinal properties (GADANO et al., 2006).

The wide use of the Santa Maria herb is due to the presence of high levels of ascaridole in the seeds, leaves, and stem. It is mainly used for the treatment of ascaridiasis, and has been demonstrated to be effective in the control of Ascaridia sp. in Japanese quails (VITA et al., 2015). Few authors have reported the efficacy of the aqueous extract against gastrointestinal nematodes in small ruminants (SILVA, 2012) and hexane and dichloromethane extracts against Toxocara canis larvae (REIS et al., 2010).

According to Costa et al. (2002), the scientific validation of phytochemical therapeutics is a mandatory step for the correct use of medicinal plants or their active compounds, and in vitro tests allow for discovery of anthelminthic properties in plant extracts, allowing the development of new alternatives for the control of parasites.

In the control of nematode infections, drugs are used, which can have unpleasant and unpalatable flavors, which hinder their administration in dogs. To our knowledge, no study on the activity of $C$. ambrosioides on Ancylostoma spp., as well as its incorporation in dogcookies currently exists in the literature. Sousa et al. conducted a survey of anthelmintic activity of native plants of the American continent in 2013, but did not report use of C. ambrosioides on Ancylostoma spp.

The objective of this study was to determine the yield and characterize the chemical composition of the essential oil of $C$. ambrosioides, as well as to evaluate the in vitro effects of the ethanolic extract and the essential oil on L3 larvae of Ancylostoma spp. and the in vivo effects of the essential oil in dogs.

\section{Materials and Methods}

The aerial parts of $C$. ambrosioides were collected in the morning from plants grown in a greenhouse, located in the municipality of Alegre, Espírito Santo State, Brazil, at coordinates of $20^{\circ} 44$ ' $49^{\prime}$ ', latitude $\mathrm{S}, 41^{\circ} 27$ ' $58^{\prime}$ ' with a longitude $\mathrm{W}$ and an altitude of $250 \mathrm{~m}$. The exsiccate is deposited in the Sector VIES Herbarium of Jerônimo Monteiro, under registration VIES 21536.

To prepare the ethanolic extract, the leaves were dried in a drying chamber at $40^{\circ} \mathrm{C}$ with dehumidifier until their weight remained constant. Dried leaves were then ground to form powder with a grinder (Walita HR2943 / 00), which was added to $20 \%$ ethanol (weight/volume) (Vetec a $99.8 \%$ PA). This mixture was kept at $27 \pm 2{ }^{\circ} \mathrm{C}$ protected from light for one week, then filtered, remacerated three more times, and concentrated in a rotary evaporator at 
$40^{\circ} \mathrm{C}$ under reduced pressure to yield the ethanolic extract which was $6 \%$ of starting leaf weight. Fortyfive grams of extract were obtained, which was stored at $4^{\circ} \mathrm{C}$ until use.

The essential oil was obtained from $100 \mathrm{~g}$ of fresh leaves by hydrodistillation for 3 hours in a Clevenger apparatus. After obtaining $300 \mathrm{~mL}$ of hydrolysate (water + oil), the oil was extracted from the aqueous phase using pentane $(5 \times 30 \mathrm{~mL})$ as the solvent. Anhydrous sodium sulfate was added to the organic phase to remove water. The anhydrous remainder was filtered, and pentane was removed by rotary evaporator. The essential oil obtained was conditioned in an amber glass bottle wrapped with aluminum foil and stored at $4^{\circ} \mathrm{C}$ (CASTRO et al., 2004; COSTA et al., 2013; PINHEIRO et al., 2013).

Identification of volatile components present in the oil was performed by gas chromatography coupled to a mass spectrometer (GC-MS), with selective mass detector, model QP-PLUS-2010 (SHIMADZU). Chromatography was performed with a fused silica capillary column with Rtx-5MS stationary phase, $30 \mathrm{~m}$ long and $0.25 \mathrm{~mm}$ internal diameter, using helium as the entrained gas. The temperatures were $220{ }^{\circ} \mathrm{C}$ in the injector and 300 ${ }^{\circ} \mathrm{C}$ in the detector. The initial temperature of the column was $60^{\circ} \mathrm{C}$, programmed to increase by $3{ }^{\circ} \mathrm{C}$ every minute, to a maximum temperature of 240 ${ }^{\circ} \mathrm{C}$ (CASTRO et al., 2004; COSTA et al., 2013; PINHEIRO et al., 2013).

Compounds were identified by comparing their mass spectra with reference data from the equipment database (NIST / EPA / NIH 08 Spectral Mass Library), and with literature and Kovats indexes (ADAMS, 2007).

The chemical constituents of the essential oil were quantified by gas chromatography on a SHIMADZU GC-2010 Plus instrument equipped with a flame ionization detector (CG-DIC). The entrainment gas used was nitrogen and the column was a capillary column Rtx-5MS, $30 \mathrm{~m}$ long and $0.25 \mathrm{~mm}$ internal diameter. The injector and detector temperatures were set at 240 and $250{ }^{\circ} \mathrm{C}$, respectively. The temperature setting in the oven was the same as that used in GC-MS analyses. The relative percentage of each component of the essential oil was calculated by the ratio of the area under its respective peaks over the total area under all peaks in the sample (CASTRO et al., 2004).

This experiment was approved by the Ethics Committee on Animal Experimentation of the Faculdade de Filosofia, Ciências e Letras of Alegre, ES, under number 0200018/2010.

The in vitro tests with ethanol extract and essential oil were performed in duplicate for each group by mixing $500 \mu \mathrm{L}$ of extract or oil with 500 $\mu \mathrm{L}$ of the solution containing $\mathrm{L} 3$ larvae in a $1.5 \mathrm{~mL}$ polypropylene tube. After 48 hours of treatment, according to the method of Reis et al. (2010), $10 \mu \mathrm{L}$ of the solution was deposited on a glass slide and motility of 30 larvae per field was examined under 40x light microscopy. Larval activity was evaluated according to the rubric of Reis et al. (2010), in which $0=$ dead; 1 = immobile, but not dead; 2 = partial body movement; 3 = slow whole body movement; 4 intermediate whole body movement; $5=$ rapid whole body movement. Results are presented as percentages of total represented by each possible score. The larvae of Ancylostoma spp. were obtained by fecal culture, adapted from Ueno and Gonçalves (1998).

The following groups were evaluated in vitro: Group A (negative control - distilled water); group B1 (positive control - anthelmintic albendazole); group B2 (positive control - praziquantel combination, pyrantel pamoate and febantel in liquid commercial form); group C (ethanolic extract (EE) of $C$. ambrosioides at concentrations: $\mathrm{C} 1$ : $0.005 \mathrm{~g} \mathrm{~mL}^{-1}$; $\mathrm{C} 2: 0.01 \mathrm{~g} \mathrm{~mL}^{-1}$; $\mathrm{C} 3: 0.02 \mathrm{~g} \mathrm{~mL}^{-1} ; \mathrm{C} 4$ : $0.03 \mathrm{~g} \mathrm{~mL}^{-1}$; C5: $0.04 \mathrm{~g} \mathrm{~mL}^{-1}$; 6 : $0.05 \mathrm{~g} \mathrm{~mL}^{-1} ; \mathrm{C} 7$ : $0.06 \mathrm{~g} \mathrm{~mL}^{-1}$; C8: $0.08 \mathrm{~g} \mathrm{~mL}^{-1}$; C9: $0.1 \mathrm{~g} \mathrm{~mL}^{-1}$; C10: $0.12 \mathrm{~g} \mathrm{~mL}^{-1}$; $\mathrm{C} 11: 0.2 \mathrm{~g} \mathrm{~mL}^{-1}$ ); group D (essential oil (EO) of C. ambrosioides at concentrations: D1: 50 $\mu \mathrm{L} \mathrm{mL} L^{-1}$; D2: $100 \mu \mathrm{L} \mathrm{mL}^{-1}$ and D3: $150 \mu \mathrm{L} \mathrm{mL}^{-1}$ ); 
and group E (solvent) E1: Propylene glycol and E2: Polysorbate.

For the in vivo test, 26 healthy dogs, aged over six months, weighing between 12 and $15 \mathrm{~kg}$ of live weight, without distinguishing breed or sex, were used, and not pregnant and housed in the Zoonosis Control Center (CCZ) in the Municipality of Serra, Espírito Santo. They were fed commercial feed and water ad libitum. During the treatment, the dogs were isolated in kennels with access to sunlight, away from other animals. After clinical and laboratory evaluation, otherwise healthy animals with natural infection by Ancylostoma spp. were selected for the study.

Cookies were prepared according to the following formula: 1) water and salt cookie- 1.6 g (40\%); 2) 20\% pharmaceutical gelatin solution $-0.4 \mathrm{~g}(10 \%) ; 3)$ vegetable fat - $0.2 \mathrm{~g}(5 \%) ; 4)$ moist meat flavored ration $-0.4 \mathrm{~g}(10 \%) ; 5) C$. ambrosioides essential oil - $150 \mu \mathrm{L}$; 6) dry ration pellet - q.s.p. 4 g. After mixing, cookies were molded and placed in an oven at $40^{\circ} \mathrm{C}$ for 4 hours. The final concentration of essential oil in each cookie was $37.5 \mu \mathrm{L} \mathrm{g}^{-1}$. The animals were divided into three experimental groups: Group F1: Dogs treated with cookies without active principle $(n=9)$; Group F2: Dogs treated with cookie with essential oil of C. ambrosioides L. $(\mathrm{n}=10)$; Group F3: Dogs treated with cookie plus commercial product based on febantel, pyrantel, praziquantel, and ivermectin $(\mathrm{n}=7)$. Each F1 and F2 animal received treatment at the initial time (M1), one cookie per day for three consecutive days, with repetition after 15 days. F3 animals received a single dose of the commercial drug combination in cookie formulation at the dose recommended by the manufacturer. This dose was repeated after 15 days.

Blood samples were collected from the cephalic vein for laboratory analysis. For blood counts, the blood was collected at two time points: T1 - initial time, immediately before the first administration of medication, and T2 - final time, 21 days after first administration of the medication. This blood was stored in $10 \%$ EDTA tubes and processed in a Mindray BC- 2800Vet hematology autoanalyzer. Differential counts of leukocytes were obtained from blood smears stained with a Pantico rapid kit (NewProv $\left.{ }^{\circledR}\right)$.

Serum alanine aminotransferase (ALT), aspartate aminotransferase (AST), alkaline phosphatase (FA), urea, creatinine, total protein, and albumin were analyzed in a Bioplus Bio-200® biochemical analyzer.

To verify the ability of the cookies to reduce numbers of Ancylostoma spp. eggs, fecal samples were obtained from the rectum of naturally infected dogs. Eggs were detected by the method described by Willis (1921), and quantified by flotation and counting of eggs per gram of feces (EPG) (SLOSS et al., 1999). Fecal samples were collected at two time points, immediately prior to administration of cookies, and 21 days after the initial administration of cookies. Percent reduction of EPG of feces between initial and final time points was calculated for each group.

Values obtained were analyzed by the parametric $\mathrm{T}$ test paired using the program BioEstat 5.0. $\mathrm{P}$ values of 0.05 or less were taken to indicate statistical significance.

\section{Results and Discussion}

The essential oil was obtained from the aerial tissues of $C$. ambrosioides in a yield of $0.3 \%$ $\mathrm{m} \mathrm{v}^{-1}$. Gas chromatographic analysis allowed the quantification of $98.81 \%$ of the chemical constituents present in this essential oil. The major components were: (Z)-ascaridole (87\%), (E)ascaridole (5.04\%) and p-cymene $(4.83 \%)$ in lower percentages of $\alpha$-terpinene (1.24\%).

Singh et al. (2008) described $\alpha$-terpinene as the major compound of the essential oil of $C$. ambrosioides. Tapondjou et al. (2002) reported that p-cymene corresponded to $50 \%$ of the 
chemical composition of the essential oil obtained in Cameroon; in this work, only $4.83 \%$ was p-cymene. The monoterpene ascaridole [major components (isomer $\mathrm{Z}(87 \%)$ and isomer and $\mathrm{E}$ (5.04\%)] constituted only $0.7 \%$ of the essential oil in Cameroon (CHEKEM et al., 2009, 2010). Environmental stimuli can redirect metabolic routes, causing biosynthesis of different compounds.
In the in vitro test, groups $\mathrm{A}, \mathrm{E}$, and $\mathrm{C} 1$ to $\mathrm{C} 11$ did not inhibit larval activity. All of these samples scored 5. Groups B1 and B2, containing commercial drugs, scored 2 and 3, respectively. Groups D1 and D2 scored 4 and 3, respectively, and D3 scored zero (Table 1).

Table 1. Results of in vitro testing of the anthelmintic activity of Chenopodium ambrosioides towards infective larvae of Ancylostoma spp.

\begin{tabular}{llccc}
\hline Groups & Test & Score & $\begin{array}{c}\text { \% living } \\
\text { larvae }\end{array}$ & $\begin{array}{c}\text { \% immobile } \\
\text { larvae }\end{array}$ \\
\hline A (negative control) & distilled water & 5 & 100,00 & 0,00 \\
B1 (positive control) & Albendazole & 2 & 35,00 & 65,00 \\
B2 (positive control) & Praziquantel, pirantel pamoate and febantel & 3 & 38,33 & 61,67 \\
C1 a C11 (treatment EE) & ethanolic extract & 5 & 100,00 & 0,00 \\
D1 (treatment EO) & $50 \mu \mathrm{L} \mathrm{mL}^{-1}$ essential oil & 4 & 88,33 & 11,66 \\
D2 (treatment EO) & $100 \mu \mathrm{L} \mathrm{mL}^{-1}$ essential oil & 3 & 95,00 & 5,00 \\
D3 (treatment EO) & $150 \mu \mathrm{L} \mathrm{mL}^{-1}$ essential oil & 0 & 0,00 & 100,00 \\
\hline
\end{tabular}

Groups $\mathrm{C} 1$ to $\mathrm{C} 11$ did not demonstrate toxicity in vitro towards infective larvae (L3) of Ancylostoma spp. All larvae of these groups were diluted with propylene glycol and remained alive, demonstrating that the solvent used to solubilize ethanol extracts did not kill the larvae or inhibit their activity.

In in vitro tests of the essential oil, $88.33 \%$ of the larvae treated with $50 \mu \mathrm{L} \mathrm{mL}^{-1}$ (D1) scored 4 and $11.66 \%$ of them scored 0 . Ninety-five percent of larvae treated with $100 \mu \mathrm{L} \mathrm{mL} \mathrm{m}^{-1}$ essential oil (D2) scored 3, and 5\% scored 0 . With the essential oil at the concentration of $150 \mu \mathrm{L} \mathrm{mL}^{-1}$ (D3) the larval activity was $100 \%$. This essential oil contains ascaridole, a monoterpene found in large amounts in the leaves and fruits of Chenopodium ambrosioides L. The plants in this study contained $87 \%$ (Z)ascaridole, which behaves as a potent anthelmintic agent (CASTELLANOS, 2008).

In in vivo test subjects, a reduction in the red cell count $(p=0.01)$, hematocrit $(p=0.01)$, and CHCM ( $p=0.001)$ were observed in group F1. A reduction in CHCM was observed in group F2 (p = $0.04)$, while a reduction in lymphocytes $(p=0.03)$ and increase in monocytes $(p=0.03)$ were observed in group F3. Albumin was reduced in F1 serum ( $p$ $=0.01)$. In group F2, increases were seen in serum proteins $(\mathrm{p}=0.005)$ and globulins $(\mathrm{p}=0.001)$. In group F3, albumin decreased $(p=0.007)$ and globulins increased $(p=0.006)$.

In the in vivo test, the F1 group experienced a significant reduction in red blood cell parameters $(p=0.01)$, hematocrit $(p=0.01)$, and CHCM $(p=$ $0.001)$ associated with albumin reduction $(p=0.01)$, suggests that the cause is the parasitic infection itself during the drug test period. These results highlight the importance of treatment because an infected animal can develop anemia and hypoalbuminemia in a short time.

Group F2 dogs, treated with $37.5 \mu \mathrm{L} \mathrm{g}^{-1} C$. ambrosioides essential oil, exhibited significant reduction in CHCM $(\mathrm{p}=0.04)$ and increase in serum proteins $(\mathrm{p}=0.005)$ and globulins $(\mathrm{p}=$ 
0.001). Pereira et al. (2010) treated mice with a hydroalcoholic extract of leaves of $C$. ambrosioides at a dose of $5 \mathrm{mg} \mathrm{kg}^{-1}$ for 15 days and observed an immune response with a significant increase in the number of hematopoietic cells.

The F3 group experienced a significant reduction in lymphocytes $(p=0.03)$ and an increase in monocytes $(p=0.03)$ over the course of the study. However, both pre- and post-treatment values were within reference standards described by Weiss and Wardrop (2010). Reduced albumin $(p=0.007)$ and increased globulin $(p=0.006)$ concentrations were also observed in this group.

We observed a $7.42 \%$ reduction in EPG in the $\mathrm{F} 1$ group, $82.14 \%$ reduction in the F2 group, and $100 \%$ reduction in F3. The reduction in EPG in the F2 group was statistically significant $(p<0.001)$. Although treatment with essential oil of $C$. ambrosioides did not yield negative results upon parasitological examination, the reduction in EPG can be considered satisfactory because the small amount of remaining antigen is expected to stimulate the immune system. Furthermore, according to the efficacy index for adult parasites proposed by the World Association for the Advancement of Veterinary Parasitology (WAAVP), a product is considered effective when the reduction in egg counts is greater than $90 \%$ and moderately effective when this reduction is between $80 \%$ and $90 \%$ (COLES et al., 1992).

\section{Conclusions}

Based on the results of this study, we concluded that the ethanolic extract of $C$. ambrosioides $\mathrm{L}$. did not possess anthelmintic efficacy towards L3 Ancylostoma spp. larvae. The essential oil of $C$. ambrosioides L., at a concentration of $150 \mu \mathrm{L} \mathrm{mL}^{-1}$, was effective in vitro against third-stage larvae of Ancylostoma spp., and the herbal cookies containing $37.5 \mu \mathrm{L} \mathrm{g}^{-1}$ of $C$. ambrosioides $\mathrm{L}$. essential oil significantly reduced the EPG in feces of dogs naturally infected with Ancylostoma spp.

\section{References}

ADAMS, R. P. Identification of essential oil components by gas chromatography/mass spectroscopy. Illinois: Allured, 2007. 804 p.

CASTELlANOS, J. R. G. Epazote (C. ambrosioides). A revision to its morphological characteristics, pharmacological activity, and the biogenesis of its principal active ingredient, ascaridole. Boletin Latinoamericano y Del Caribe de Plantas Medicinales y Aromaticas, Santiago, v. 7, n. 1, p. 3-9, 2008.

CASTRO, H. G.; OLIVEIRA, L. O.; BARBOSA, L. C. A.; FERREIRA, F. A.; SILVA, D. J. H.; MOSQUIM, P. R.; NASCIMENTO, E. A. Teor e composição do óleo essencial de cinco acessos de mentrasto. Química Nova, São Paulo, v. 27, n. 1, p. 55-57, 2004.

CHEKEM, M. S. G.; LUNGA, P. K.; TAMOKOU, J. D. D.; KUIATE, J. R.; TANE, P.; VILAREM, G.; CERNY, M. Antifungal properties of Chenopodium ambrosioides essential oil against Candida Species. Pharmaceuticals, Switzerland v. 3, n. 9, p. 2900-2909, 2010.

COLES, G. C.; BAUER, C.; BORGSTEEDE, F. H. M.; GEERTS, S.; KLEI, T. R.; TAYLOR, M. A.; WALLER, P. J. World Association for the Advancement of Veterinary Parasitology (W.A.A.V.P.) methods for the detection of anthelmintic resistance in nematodes of veterinary importance. Veterinary Parasitology, Basel, v. 44, n. 1-2, p. 35-44, 1992.

COSTA, A. V.; PINHEIRO, P. F.; RONDELLI V. M.; QUEIROZ, V. T.; TULER, A. C.; BRITO, K. B.; STINGUEL, P.; PRATISSOLI, D. Cymbopogon citratus (Poaceae) essential oil on Frankliniella schultzei (Thysanoptera: Thripidae) and Myzus persicae (Hemiptera: Aphididae). Bioscience Journal, Uberlândia, v. 29, n. 6, p. 1840-1847, 2013.

COSTA, C. T. C.; MORAIS, S. M. de; BEVILAQUA, C. M. L.; SOUZA, M. M. C. de; LEITE, F. K. A. Efeito ovicida de extratos de sementes de Mangifera indica L. sobre Haemonchus contortus. Revista Brasileira de Parasitologia Veterinaria, Jaboticabal, v. 11, n. 2, p. $57-$ 60, 2002.

GADANO, A. B.; GURNI, A. A.; CARBALlO, M. A. Argentine folk medicine: Genotoxic effects of Chenopodiaceae family. Journal of Ethnopharmacology, Copenhagen, v. 103, n. 2, p. 246-25, 2006.

PEREIRA, W. S.; RIBEIRO, B. P.; SOUSA, A. I.; SERRA, I. C.; MATTAR, N. S.; FORTES, T. S. REIS, A. S.; SILVA, L. A.; BARROQUEIRO, E. S.; GUERRA, R. N.; NASCIMENTO, F. R. Evaluation of the subchronic 
toxicity of oral treatment with C. ambrosioides in mice. Journal of Ethnopharmacology, Copenhagen, v. 127, n. 3, p. 602-605, 2010.

PINHEIRO P. F.; QUEIROZ, V. T.; RONDELLI V. M.; COSTA, A. V.; MARCELINO T. P.; PRATISSOLI, D. Insecticidal activity of citronella grass essential oil on Frankliniella schultzei and Myzus persicae. Ciência e Agrotecnologia, Lavras, v. 37, n. 2, p. 138-144, 2013.

REIS, M.;TRINCA,A.;FERREIRA, M. J.; MONSALVEPUELLO, A. R.; GRÁCIO, M. A. Toxocara canis: Potential activity of natural products against second-stage larvae in vitro and in vivo. Experimental Parasitology, Berlin, v. 126, n. 2, p. 191-197, 2010.

SILVA, G. D. Avaliação da atividade anti-helmíntica e toxicológica do extrato aquoso de Chenopodium ambrosioides (mastruz) sobrenematoides gastrintestinais de caprinos. 2012. Dissertação (Ciência Animal nos Trópicos) -Universidade Federal da Bahia, Bahia.

SINGH, H. P.; BATISH, D. R.; KOHLI, R. K.; MITTAL, S.; YADAV, S. Chemical composition of essential oil from leaves of Chenopodium ambrosioides from Chandigarh, India. Chemistry of Natural Compounds, New York, v. 44, n. 3, p. 378-379, 2008.

SLOSS, M. W.; ZAJAC, A. M.; KEMP, R. L. Parasitologia clínica veterinária. São Paulo: Manole, 1999. 198p.
SOUSA, R. G.; FALCÃO, H. S.; BARBOSA FILHO, J. M.; MELO DINIZ, M. F. F.; BATISTA, L. M. Atividade anti-helmíntica de plantas nativas do continente americano: uma revisão. Revista Brasileira de Plantas Medicinais, Campinas, v. 15, n. 2, p. 287-292, 2013.

TAPONDJOU, L. A.; ALDER, A.; BONDA, H.; FONTEM, D. A. Effi cacy of powder and essential oil from Chenopodium ambrosioides leaves as post-harvest grain protectants against six-stored product beetles. Journal of Stored Products Research, Amsterdam, n. 4, v. 38, p. 395-402, 2002.

UENO, H.; GONÇALVES, P.C. Manual para diagnóstico das helmintoses de bovinos. Toquio: JIICA, 1998. $143 \mathrm{p}$.

VITA, G. F.; FERREIRA, I.; PEREIRA, M. A. V. C. da; SANAVRIA, A.; AURNHEIMER, R. de C. M.; BARBOSA, C. G.; GALlO, S. S. M. E.; VASCONCELLOS, H. V. G. Eficácia de Chenopodium ambrosioides (erva-de-santa-maria) no controle de endoparasitos de Coturnix japônica (codorna japonesa.). Pesquisa Veterinária Brasileira, Seropédica, v. 35, n. 5, p. 424-430, 2015.

WEISS, D. J.; WARDROP, K. J. Schalm's veterinary hematology. $6^{\text {th }}$ ed. Oxford: Willey-Blackwell, 2010, $1206 \mathrm{p}$.

WILLIS, H. H. A simple levitation method for the detection of hookworm ova. Medical Journal Australia, Sydney, v. 2, n. 18, p. 375-37, 1921. 
